\title{
Pea, Lentil and Chickpea Protein Application in Bread Making
}

\author{
Mohammed Aider ${ }^{1}$, Maxime Sirois-Gosselin ${ }^{2} \&$ Joyce Irene Boye ${ }^{3}$ \\ ${ }^{1}$ Department of Food Engineering, Université Laval, Quebec, Canada \\ ${ }^{2}$ Department of Biotechnological Engineering, Université de Sherbrooke, Sherbrooke, Canada \\ ${ }^{3}$ Agriculture and Agri-Food Canada, Food Research and Development Centre, Saint-Hyacinthe, Canada \\ Correspondence: Joyce Irene Boye, Agriculture and Agri-Food Canada, Food Research and Development Centre, \\ 3600 Casavant Blvd. West, Saint-Hyacinthe, Que. J2S 8E3, Canada. Tel: 1-450-768-3232. E-mail: \\ Joyce.Boye@agr.gc.ca
}

Received: August 6, 2012 Accepted: August 29, 2012 Online Published: October 29, 2012

doi:10.5539/jfr.v1n4p160 URL: http://dx.doi.org/10.5539/jfr.v1n4p160

\begin{abstract}
The objective of the present study was to determine if wheat flour could be successfully substituted with lentil, pea, and chickpea (pulses) proteins in bread making and to study the characteristics of the breads produced. Results of the study showed that addition of pulse proteins affected bread mass volume, color and hardness. The highest bread mass volume $(4.27 \pm 0.07 \mathrm{~mL} / \mathrm{g})$ was obtained with the control (unsupplemented) bread. Mass volumes decreased at the 3\% supplementation level for all supplemented breads and no significant differences $(\mathrm{P}>0.05)$ were observed between the pulse proteins. At the $6 \%$ and $9 \%$ supplementation levels, significant differences were observed between the mass volumes of the breads. Chickpea protein gave the highest mass volume at both the $6 \%$ and $9 \%$ supplementation levels $(3.72 \pm 0.21$ and $3.84 \pm 0.27 \mathrm{~mL} / \mathrm{g}$, respectively) followed by lentil protein $(3.43 \pm 0.19$ and $3.43 \pm 0.07 \mathrm{~mL} / \mathrm{g}$, respectively). Breads supplemented with pea protein generally had the lowest mass volume. Bread crumb and white became darker as supplementation level was increased and in the lentil supplemented bread, a greener color appeared at the $6 \%$ and $9 \%$ supplementation levels. Hardness of the bread white for all supplemented samples was close to the control at the $3 \%$ supplementation level but significantly increased at the $9 \%$ supplementation level. Overall, pea proteins had the most significant effect on bread hardness and mass volume whereas chickpea protein concentrate showed the greatest potential for use as an ingredient in bread making.
\end{abstract}

Keywords: bread, lentil, pea, chickpea, protein, pulses, loaf mass volume, hardness

\section{Introduction}

Bread remains an important component of the human diet and constitutes one of the most important sources of nutrients such as proteins, fibres, minerals and vitamins in the diets of many cultures. In the last two decades, an increased trend towards healthy eating has resulted in the development of many novel functional foods. Plant ingredients are known to have health benefits and their use in different food matrices offers the opportunity to increase their consumption. Legumes such as lentil, pea, and chickpea, are an important source of proteins, carbohydrates, vitamins and minerals and are widely consumed in some traditional diets (Chavan et al., 1986; Dodok et al., 1993). These crops are particularly important in the diet of Asian Mediterranean and African populations (Annapure et al., 1998). Not too surprisingly, interest in their consumption is also increasing in Europe, North and South America as research exposes more information about their potential health benefits.

Pulse crops contain relatively high amounts of protein (23-27\%) but they are low in lipid content (1-7.2\%) (Dodok et al., 1993). One of the most important properties of pulse proteins is their high content of lysine, an essential amino acid, and their deficiency in sulphur containing amino acids which makes them great compliments to other well-known cereal proteins (e.g., wheat) which are deficient in lysine, but have good content of sulphur amino acids (Eggum \& Beame, 1983). Combining cereal and pulse proteins helps to overcome the deficiencies of these crops, by balancing the amino acid profiles deficiency which can markedly improve protein quality (Livingstone et al., 1993). Furthermore, some studies have shown additional benefits of pulse flour use such as an increase in mineral bioavailability and lowering of glycaemic response in healthy consumers when pulses, such as chickpea flour, are added to the diet (Goni \& Valentín-Gamazo, 2003; Frost et al., 1999). 
As bread is widely consumed by many, it is a potential vehicle to consider for supplementation of pulse proteins. The objective of this study, therefore, was to determine if wheat bread could be successfully supplemented with lentil, pea, and chickpea proteins and to study the characteristics of the bread produced. Wheat flour in the basic control formula was partially substituted by these ingredients at the 3,6 and $9 \%$ supplementation levels. Loaf mass volume, texture and color of the end product were evaluated as a function of the type of pulse protein ingredient used and the supplementation level.

\section{Materials and Methods}

\subsection{Raw Materials}

All breads were prepared with bleached wheat flour purchased from the local market. The flour contained 89.44 $\pm 0.19(\%)$ total dry matter and $13.76 \pm 0.18(\%)$ total protein content. Pea, lentil and chickpea protein concentrates with protein contents of $81.4,82.5,66.8 \%$ (w/w, dry basis) was produced in-house as described by Boye et al. (2009). A commercially available pea protein concentrate (protein content, $79 \% \mathrm{w} / \mathrm{w}$, dry basis) was also obtained and used as comparison. All other materials used in bread making were obtained from the local supermarket. All chemicals used were reagent grade.

\subsection{Bread Formula}

Control bread was prepared according to the American Association of Cereal Chemists (AACC) Method 10-10B (AACC, 1983) using the following ingredients: wheat flour, sugar, salt, shortening, reactivated bread yeast and ascorbic acid. Breads were supplemented with the pulse proteins by substituting part of the wheat flour with 3, 6 and $9 \%$ of the targeted proteins. The formulation used for each bread and the corresponding amounts of ingredients are summarized in Table 1.

Table 1. Formula for bread making using pulse proteins as wheat flour substitute

\begin{tabular}{lllll}
\hline \multicolumn{5}{c}{ Formula for bread making, g } \\
\hline \multirow{2}{*}{ Ingredients } & Control & \multicolumn{3}{c}{ Substitution level } \\
\cline { 3 - 5 } & & $\underline{3 \%}$ & $\underline{6 \%}$ & $\underline{9 \%}$ \\
\hline Wheat flour & 500 & 485 & 470 & 455 \\
Sugar & 30 & 30 & 30 & 30 \\
Salt & 7.5 & 7.5 & 7.5 & 7.5 \\
Shortening & 15 & 15 & 15 & 15 \\
Yeast & 6 & 6 & 6 & 6 \\
Ascorbic acid $(0,1 \%$ w/v) & 27 & 27 & 27 & 27 \\
Total water including ascorbic acid solution & 325 & 325 & 325 & 325 \\
Pulse protein concentrates & 0 & 15 & 30 & 45 \\
\hline
\end{tabular}

\subsection{Bread Making}

Dry ingredients were mixed for $15 \mathrm{~s}$ in a 100-200 g mixer (National Mfg Co, Lincoln, Neb, U.S.A.). Water $\left(37^{\circ} \mathrm{C}\right)$ was then added, and the dough was mixed to optimum development $(4 \mathrm{~min})$. The dough was then proofed at $37^{\circ} \mathrm{C}$ and $85 \%$ relative humidity for a total period of $120 \mathrm{~min}$ with periodical punches (flaps) of the dough after $69 \mathrm{~min}$, then after $34 \mathrm{~min}$. The dough was put in moulds and proofed for another $17 \mathrm{~min}$ at $37^{\circ} \mathrm{C}$ and $85 \%$ relative humidity and baked at $210^{\circ} \mathrm{C}$ for $20 \mathrm{~min}$ in a revolving oven (Equipement de Boulangerie L. P., Victoriaville, Qc, Canada). After cooling for $1 \mathrm{~h}$, the characteristics of the breads were determined.

\subsection{Analysis}

\subsubsection{Bread Volumetric Mass}

Loaf volume was measured using the rapeseed displacement method (National Mfg. Co. Lincoln, Neb, USA) and bread volumetric mass was calculated according to the AACC 10-05 method (AACC, 2001). Briefly, the product is placed in the center of the lower housing of the volumeter. After raising the volumeter to the upright position and latching the lower housing, the gate slide is opened and the rapeseed is allowed to fill the latched 
lower housing. The volume of the product is read directly from the calibrated column, as indicated by the level of the rapeseeds in the column.

\subsubsection{Visual Evaluation}

All breads were visually evaluated according to the following parameters: form (regular or deformed), texture (smooth or rough), cracks (present or absent), white (uniform or not), alveoli (small, medium, big), colour (normal, abnormal). The supplemented breads were compared to the control sample made without any substitution.

\subsubsection{Texture Profile Analysis}

The textural property of the bread were evaluated using the TA.XT2i texture profile analysed (TPA) instrument (TA-XT2i, Texture Technologies Co. Scarsdale, NY, USA). Hardness of the bread was measured as follows: bread samples were subjected to a double compression (50\% compression) using a $5 \mathrm{~kg}$ probe in a strain target mode and a trigger force of $10 \mathrm{~g}$. The maximum force for each of the two compression phases was considered as hardness (i.e., hardness 1 or Force 1, F1 and hardness 2 or Force 2, F2).

\subsubsection{Colour Measurement}

The tristimulus color parameters $\mathbf{L}$ (Lightness (100) to Blackness (0)), a (Redness (+ve) to Greenness (-ve)), b (Yellowness (+ve) to Blueness (-ve)) of the baked breads were evaluated. Colour of the surfaces of the breads were measured with a Chroma Meter CR-300 colorimeter (Minolta Co. Osaka, Japan) using the Space colour CIE Lab system equipped with a $2^{\circ}$ observer system and calibrated with a white tile and a D-65 illuminant source.

\subsubsection{Digital Image Analysis}

The breads were sliced in $10 \mathrm{~mm}$ thick slices with an industrial slicing machine BO-20 (Equipement de Boulangerie L.P. Inc, Victoriaville, Qc, Canada). From each bread replicate, a slice was randomly selected to be scanned. The photos (in jpg format) were taken with an Epson Perfection 3490 Photo (Epson America, Inc).

\subsection{Statistical Analysis}

Analysis of variance (ANOVA) was performed and the mean comparisons were carried out by Tukey's test at 95\% confidence level. Statistical analysis was performed using the statistical software Prism-5 (GraphPad software, Inc, La Jolla, CA, USA).

\section{Results and Discussion}

\subsection{Bread Mass Volume}

The results for bread mass volume as a function of ingredient type and supplementation level are summarized in Figure 1. In all cases, the control bread had the highest mass volume with an average value of $4.27 \pm 0.07 \mathrm{~mL} / \mathrm{g}$. At the $3 \%$ supplementation level (Figure 1a), no significant difference was observed between the mass volumes of the supplemented breads $(\mathrm{P}>0.05)$. The breads supplemented with lentil $(\mathrm{L})$, pea $(\mathrm{P})$, chickpea $(\mathrm{C} / \mathrm{P})$ and commercial pea (Comm.P) protein concentrates had mass volumes of $3.69 \pm 0.11 \mathrm{~mL} / \mathrm{g}, 3.56 \pm 0.22,3.78 \pm 0.13$ and $3.79 \pm 0.17 \mathrm{~mL} / \mathrm{g}$, respectively. As the supplementation level was increased to $6 \%$, significant differences were observed between the mass volumes of the breads. At this supplementation level, the mass volume of the bread supplemented with chickpea protein had the highest mass volume $(3.72 \pm 0.21 \mathrm{~mL} / \mathrm{g})$ followed by the one supplemented with lentil protein with an average mass volume of $3.43 \pm 0.19 \mathrm{~mL} / \mathrm{g}$. The lowest mass volume was observed in the breads supplemented with pea protein and commercial pea protein with mean values of 3.13 \pm 0.07 and $3.12 \pm 0.04 \mathrm{~mL} / \mathrm{g}$, respectively (Figure $1 \mathrm{~b}$ ). When the supplementation level was increased up to $9 \%$, mass volumes of the breads supplemented with lentil and chickpea proteins were similar to the values recorded at $6 \%$ supplementation level with mean values of $3.43 \pm 0.07$ and $3.84 \pm 0.27 \mathrm{~mL} / \mathrm{g}$, respectively. However, the breads supplemented with pea protein and commercial pea protein was characterized by low mass volume compared with the results obtained for those at the 6\% supplementation level (Figure 1c). The bread prepared with pea protein had a mass volume of $2.73 \pm 0.25 \mathrm{~mL} / \mathrm{g}$ and the one supplemented with commercial pea protein showed a mass volume value of $2.39 \pm 0.13 \mathrm{~mL} / \mathrm{g}$. 

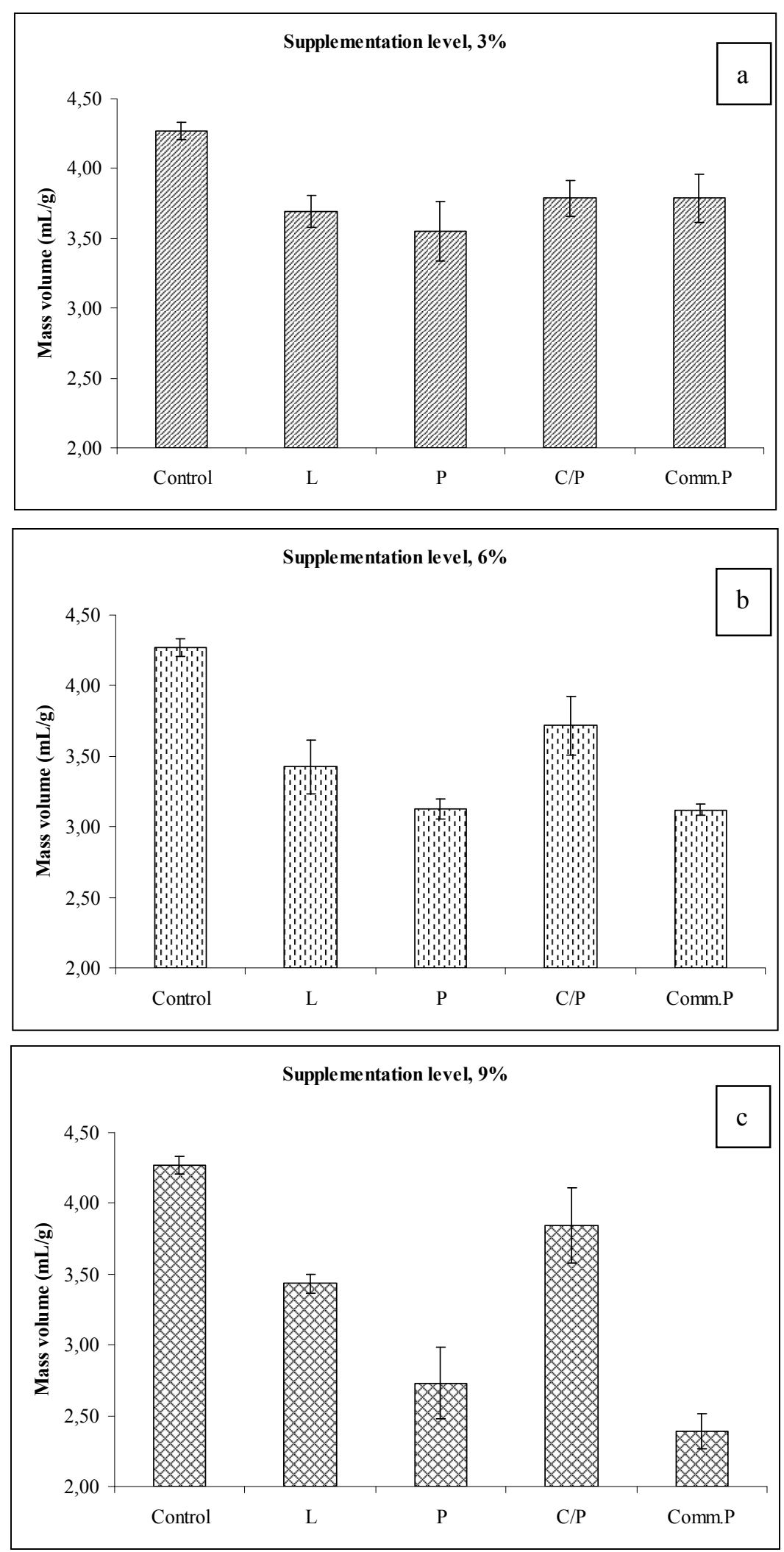

Figure 1. Bread mass volume as function of the plant protein type used and supplementation level

$\mathrm{L}$ - Lentil protein concentrate; $\mathrm{P}$ - Pea protein concentrate (in-house); C/P - Chickpea protein concentrate; Comm. $\mathrm{P}-$ Commercial pea protein concentrate. 
Wang et al. (2002) reported that pea fibre supplementation decreased specific loaf volume. Similar conclusions were also previously reported for bran, cellulose and other polysaccharides added to a bread formula (Laurikainen et al., 1998). The use of whole wheat flour dough, which contains mostly insoluble fibre, yields a normal proof height and a normal spread ratio and gives only a slight oven-spring. Laurikainen et al. (1998) attributed this behaviour to an early fixing of the structure and a high level of water in the dough structure. The lower volumetric mass of the pulse protein supplemented breads, especially at higher levels, could be due to high water absorption capacity of the added plant proteins/fibre mixture which may have lowered water vapour formation in the dough during the proofing period. In fact, water vapour together with $\mathrm{CO}_{2}$ are the two major factors influencing volume expansion of the dough and hence the volume of the loaf during the baking process. Lower water absorption capacity of the dough matrix favours higher water vapour formation which in combination with $\mathrm{CO}_{2}$ yields higher dough volume expansion and higher bread volumetric mass. Lower loaf volumes were previously reported for breads supplemented with soy protein and the behaviour was found to be concentration-dependent (Hoover, 1979). This observation is in very good agreement with the current results. In general, addition of insoluble fibre and soy protein significantly decreased loaf volume (Czuchajowska et al., 1992; Gomez et al., 2003). Similar results have been observed by other researchers and the effect has been attributed to changes in water absorption properties of the plant ingredients (Brewer et al., 1992; Vittadini \& Vodovotz, 2003).

\subsection{Visual Evaluation}

The dough of the wheat flour supplemented with the pulse proteins prepared in-house became increasingly sticky as the supplementation level was increased. The dough prepared by substituting wheat flour with commercial pea protein became firmer and very difficult to handle as the substitution level increased. Visually, all the baked breads had a shape which was similar to that of the control bread. However, they were smaller and the decrease in loaf volume became more pronounced as the supplementation level was increased. These observations are in good agreement with the mass volume measurement. Some breaks were observed on the crust of breads having a high loaf volume. As the supplementation level was increased, less breakage was observed as all the supplemented breads were smaller than the control. Visual appearance of the bread crust and white are presented in Figures 2 and 3, respectively. As the supplementation level increased, the crust appeared more undulated (i.e., rougher, bumpier). Furthermore, the crust for all the supplemented breads was darker and this tendency was more pronounced as the supplementation level increased. Lentil protein addition gave the bread white a green hue whereas the bread made with pea protein concentrate had a more yellowish hue. The crumb of the bread substituted with the chickpea protein concentrate was also yellowish, but less pronounced. The crust of the bread prepared with commercial pea protein had a beige color. For the white part of the bread (Figure 3), at the 3\% supplementation level, the loaves were characterized by a uniform crumb with alveoli comparable to those of the control bread. As the supplementation level increased, the alveoli generally appeared smaller compared to the control which correlates well with the reduced bread volume observed.

\subsection{Color Measurement}

Bread color was evaluated analytically using the L, (a) and (b) parameters previously described. L value is one of the most important color parameter as it can have a direct impact on a product's commercial value. The crumb $\mathrm{L}$ values are shown in Figure 4. Statistical analysis of the data showed that the control bread had the highest $\mathrm{L}$ value $(55.75 \pm 1.73)$ indicating greater lightness. It was followed by the $3 \%$ commercial pea protein supplemented bread with an average value of $52.41 \pm 1.90$. No significant difference $(\mathrm{P}>0.05)$ was recorded between the $\mathrm{L}$ values of the other breads which yielded $\mathrm{L}$ values ranging from $48.60 \pm 0.28$ for lentil protein supplemented bread to $50.19 \pm 0.49$ and $49.60 \pm 1.28$ for pea and chickpea protein supplemented breads, respectively. In general, the crumb $\mathrm{L}$ value tended to decrease as the supplementation level was increased for all breads except the one supplemented with the commercial pea protein which showed similar crumb L value irrespective of the supplementation level with an average value of $51.76 \pm 0.69$. The lowest $\mathrm{L}$ values were observed at the $9 \%$ supplementation level with mean values ranging from around $40.5 \pm 1.17$ to $42.60 \pm 1.32$. 


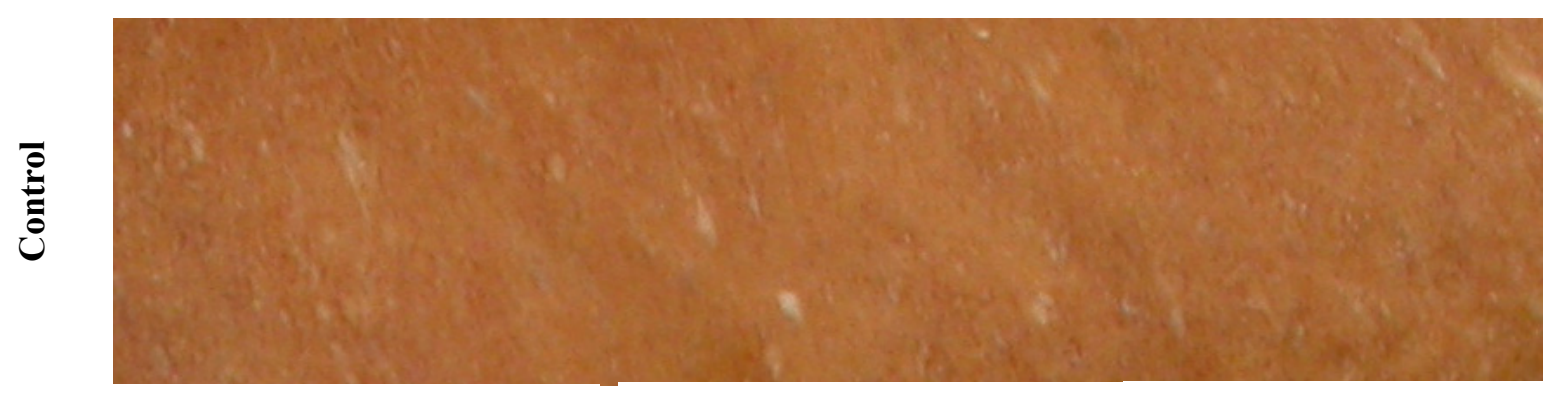

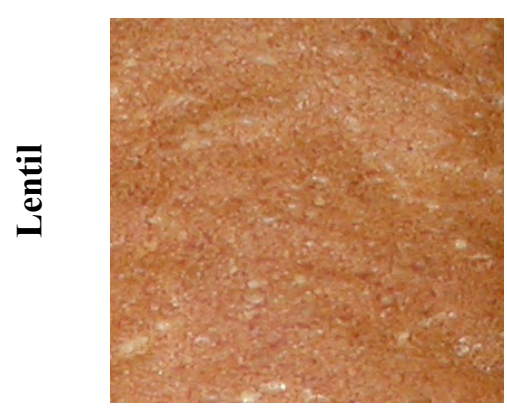
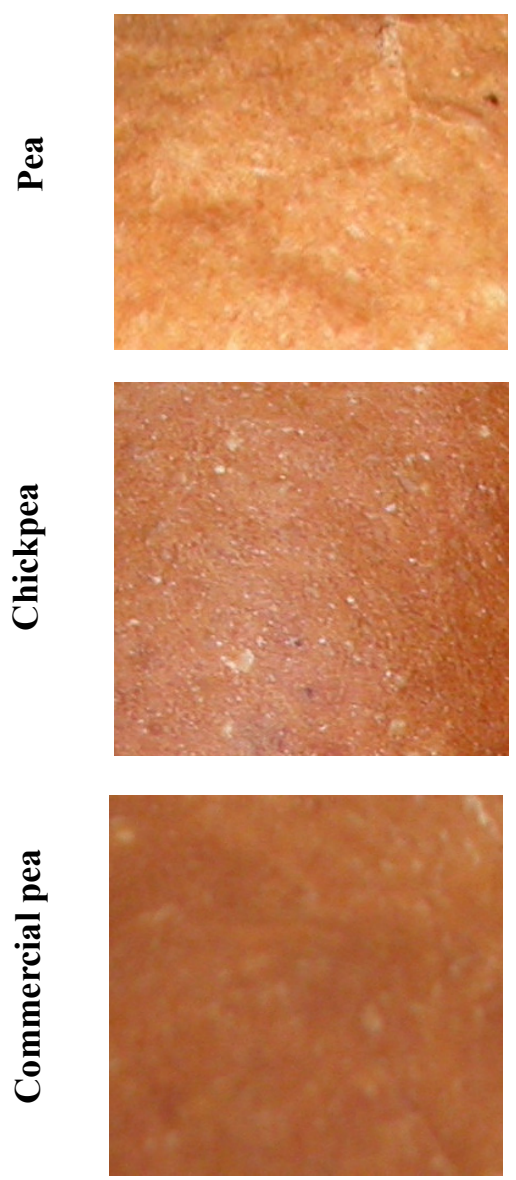

$3 \%$
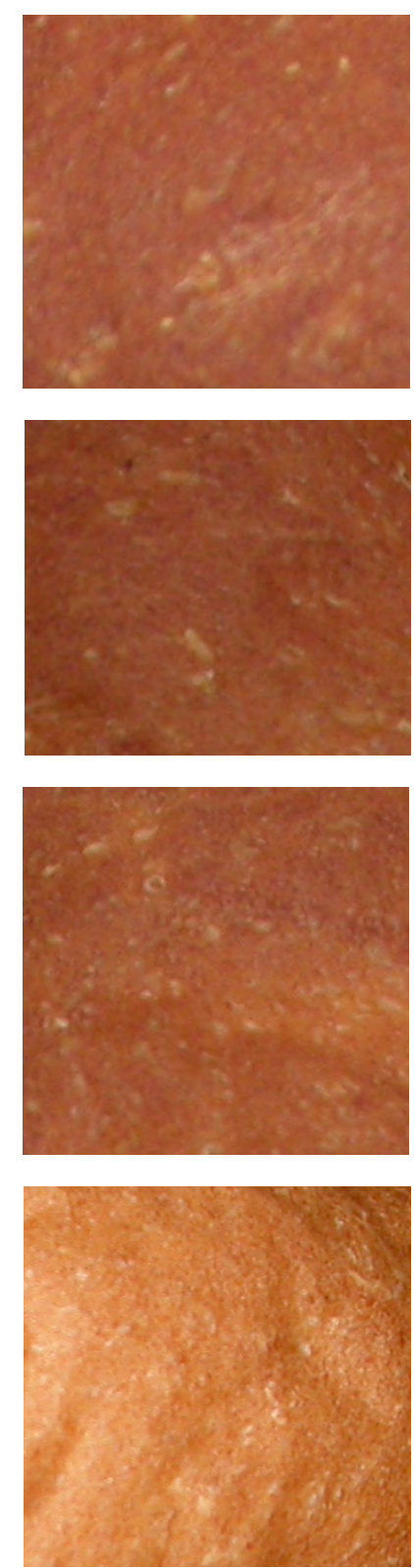

Figure 2. Visual appearance of the bread crumb of control wheat bread and bread prepared by supplementing wheat flour with 3,6 and 9\% lentil protein concentrate, pea protein concentrate (in-house), chickpea protein concentrate and a commercial pea protein concentrate
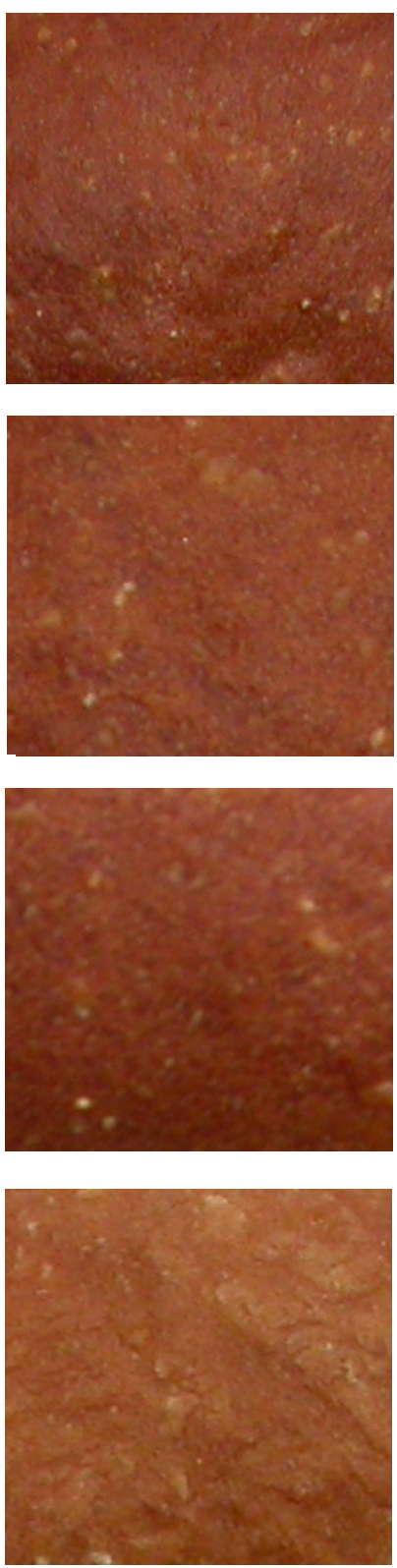

$6 \%$ 

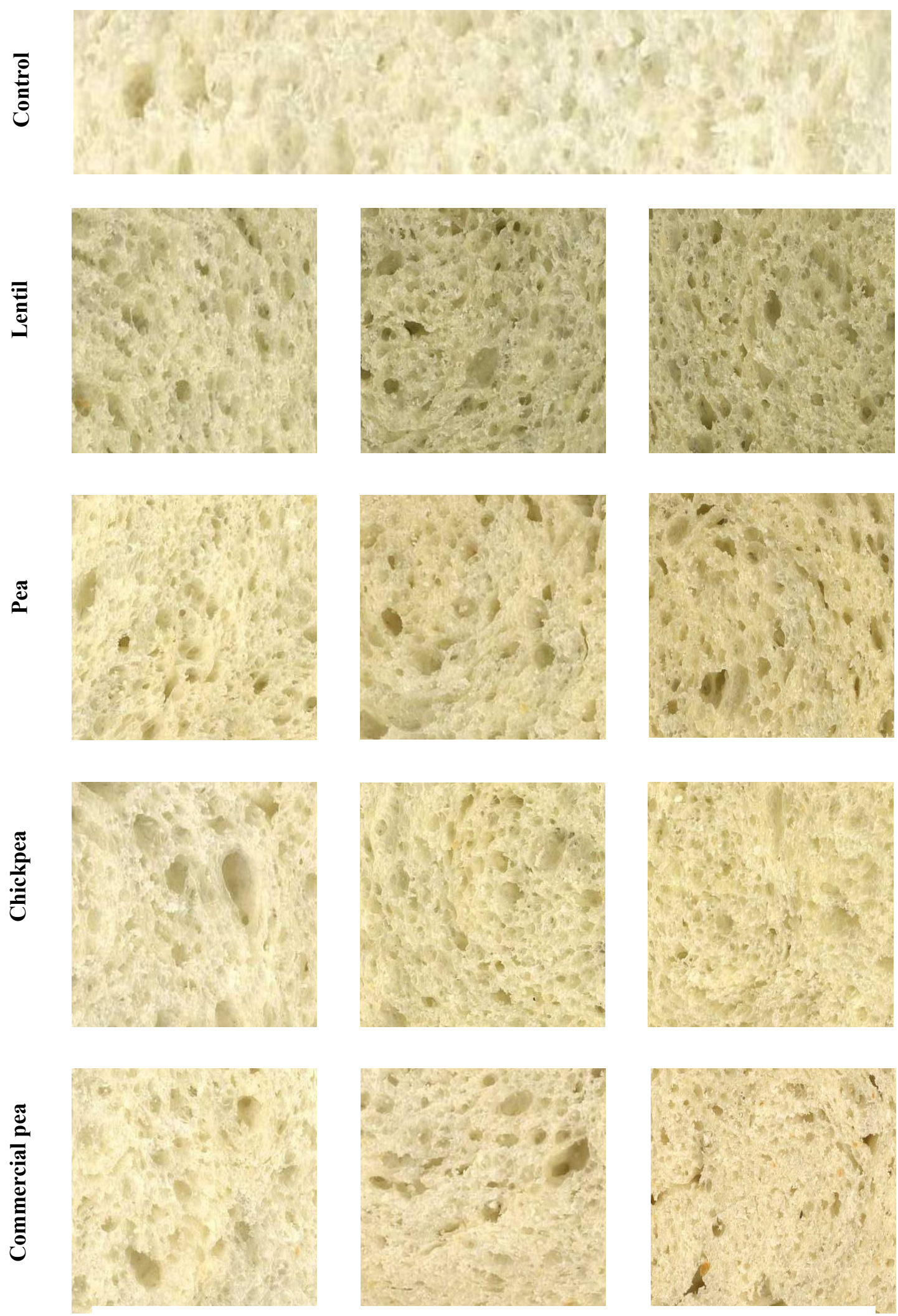

$3 \%$

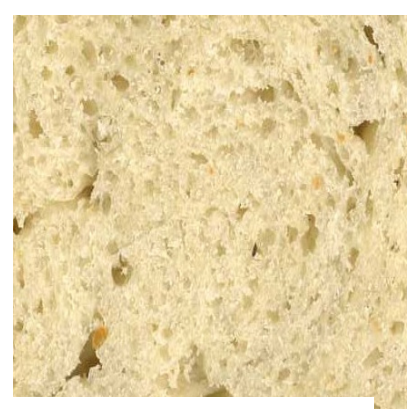

$6 \%$

Figure 3. Visual appearance of the bread white of control wheat bread and bread prepared by supplementing wheat flour with 3, 6 and $9 \%$ lentil protein concentrate, pea protein concentrate (in-house), chickpea protein concentrate and a commercial pea protein concentrate 
The $\mathrm{L}$ color parameter of the bread white was also evaluated (Figure 4a). No significant difference $(\mathrm{P}>0.05)$ was observed between the $\mathrm{L}$ value of control bread and the ones supplemented with chickpea and commercial pea proteins. The $\mathrm{L}$ mean value of these breads was $74.82 \pm 0.20$. Additionally, no significant effect of the supplementation level was observed when wheat flour was substituted by chickpea and commercial pea proteins. Bread supplemented with pea protein showed lower L values of the white than the control. Similarly, no significant differences were observed between the three supplementation levels with average value of $72.58 \pm$ 0.49 . The lowest $\mathrm{L}$ values of the bread white were determined for wheat flour substituted by lentil protein. The $\mathrm{L}$ value was $70.07 \pm 0.17$ at the $3 \%$ supplementation level and decreased to $67.06 \pm 0.68$ and $67.10 \pm 0.79$ at the 6 and $9 \%$ supplementation levels, respectively (Figure $4 b$ ).

The (a) value of the crumb and white was also considered as this parameter allowed the redness (i.e., when (a) is positive) hues of the bread to be compared. For the crust, the (a) value of all the supplemented breads was higher than that of the control (Figure 5a) which indicated that the redness hue of the crumb increased as the supplementation level was increased. In contrast, the (a) values of the majority of the supplemented samples were negative indicating the presence of some green coloration (Figure 5b) and the extent varied depending on pulse protein type and level. The results were generally in good agreement with the visual observation.

The (b) values of the bread crust and white are presented in Figure 6a and b. The results for the crust were somewhat opposite to those of the (a) value which suggested that the yellowness hue diminished as the redness hue increased. The (b) value of the control bread was the highest with an average value of $33.65 \pm 0.81$. Bread supplemented with lentil, pea and chickpea proteins had similar (b) value which decreased as the supplementation level was increased. However, in the case of the pea protein supplemented bread, no significant difference $(P>0.05)$ was observed between the samples supplemented at the 3 and $6 \%$ levels. In general, the bread supplemented with the commercial pea protein had a fairly constant (b) value at all supplementation levels with an average value of $31.29 \pm 0.49$ (Figure 6a). For the bread white, the lowest (b) value $(\mathrm{P}<0.01)$ was observed for the control sample which had an average value of $10.01 \pm 0.05$. Values for the protein supplemented breads increased as the supplementation level was increased. The highest values were recorded at the $9 \%$ supplementation level for all breads with an average value of $17.66 \pm 0.82$. In the case of the lentil protein supplemented bread, no significant difference was observed between the 3 and $6 \%$ supplementation levels and no significant difference was observed between the 6 and 9\% supplementation levels for the pea protein supplemented breads (Figure 6b).

Yamsaengsung et al. (2010) studied the effects of the addition of chickpea flour (Cicer arietinum) on the color of the crust of white and whole wheat bread. They reported that in white bread, chickpea addition increased darkness and yellowness of the bread. Indrani et al. (2007) studied the influence of adding whey protein concentrate on the color of unleavened flat bread (parotta) and found that the breads had a high (b) value, representing increased yellowness. As the whey protein concentrate level was increased from $0 \%$ (control bread) to $15 \%$, the color of the bread became dull and baked spots on the surface of bread appeared darker. Kenny et al. (2000) used whey protein concentrate with a yellowish color in bread making as wheat substitute and they found that breads made with this yellowish powder had lower $\mathrm{L}$ values compared to the control bread and a darker crust colour. The observations in this study are thus in good agreement with those reported in the scientific literature. In general, the lightness of the breads prepared with the tested ingredients was lower than that prepared with wheat flour and their addition contributed some coloration, particularly the yellowish and greenish hues, to the breads.

\subsection{Texture Profile Analysis}

The hardness of the bread whites was measured and the results are summarized as a function of the pulse protein type and supplementation level in Figure 7a and $b$. The control bread had the lowest hardness1 (Force 1) value $(1030.22 \pm 115.79 \mathrm{~g})$. This value was significantly lower than the hardness of the protein supplemented bread irrespective of the supplementation level. In the case of lentil and chickpea protein, the supplementation level did not appear to have a significant effect on bread white hardness. Lentil and chickpea supplemented bread whites had average hardness (Force 1) values of $1676.94 \pm 141.44 \mathrm{~g}$ and $1386.84 \pm 66.93 \mathrm{~g}$, respectively. For the pea (in-house) and commercial pea protein supplemented breads, the supplementation level appeared to have a significant effect on bread white hardness. For both breads, the white hardness was the highest at $9 \%$ supplementation level with mean values of $3074.40 \pm 325$ and $3884.76 \pm 133$ for pea and commercial pea protein supplemented bread, respectively. For the pea protein (in house) supplemented bread, the effect of the $3 \%$ supplementation level was similar to that of the $6 \%$ supplementation level whereas for the commercial pea protein supplemented bread, a significant difference was observed between the 3,6 and 9\% supplementation level samples (Figure 7a). Values of the hardness2 (Force 2) are summarized in Figure 7b. 

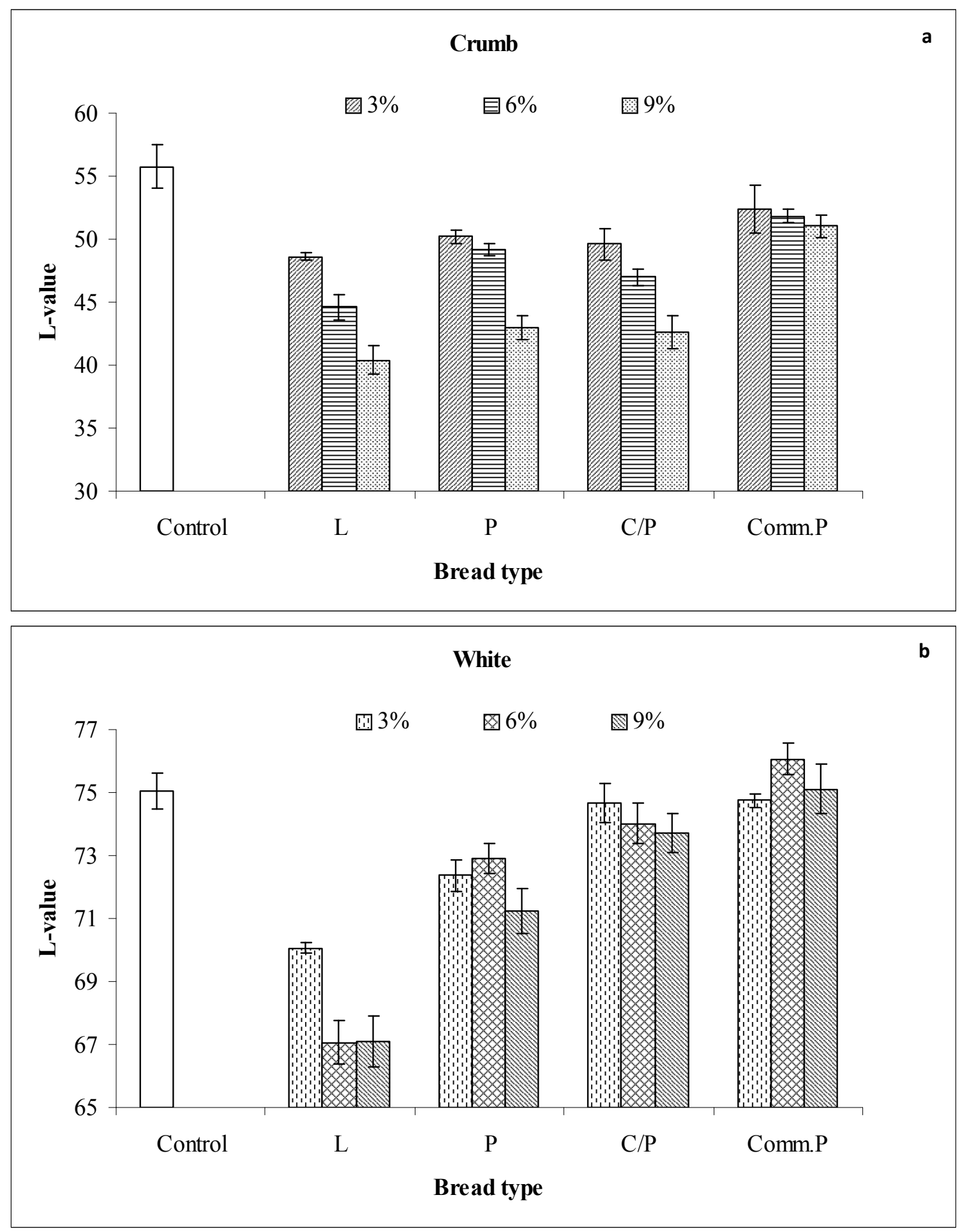

Figure 4. Evaluation of the L color parameter of (a) crumb and (b) white of control bread and supplemented bread prepared using $\mathrm{L}$ - Lentil protein concentrate; $\mathrm{P}$ - Pea protein concentrate (in-house); C/P - Chickpea protein concentrate; Comm. P - Commercial pea protein concentrate at 3,6 and $9 \%$ supplementation levels 

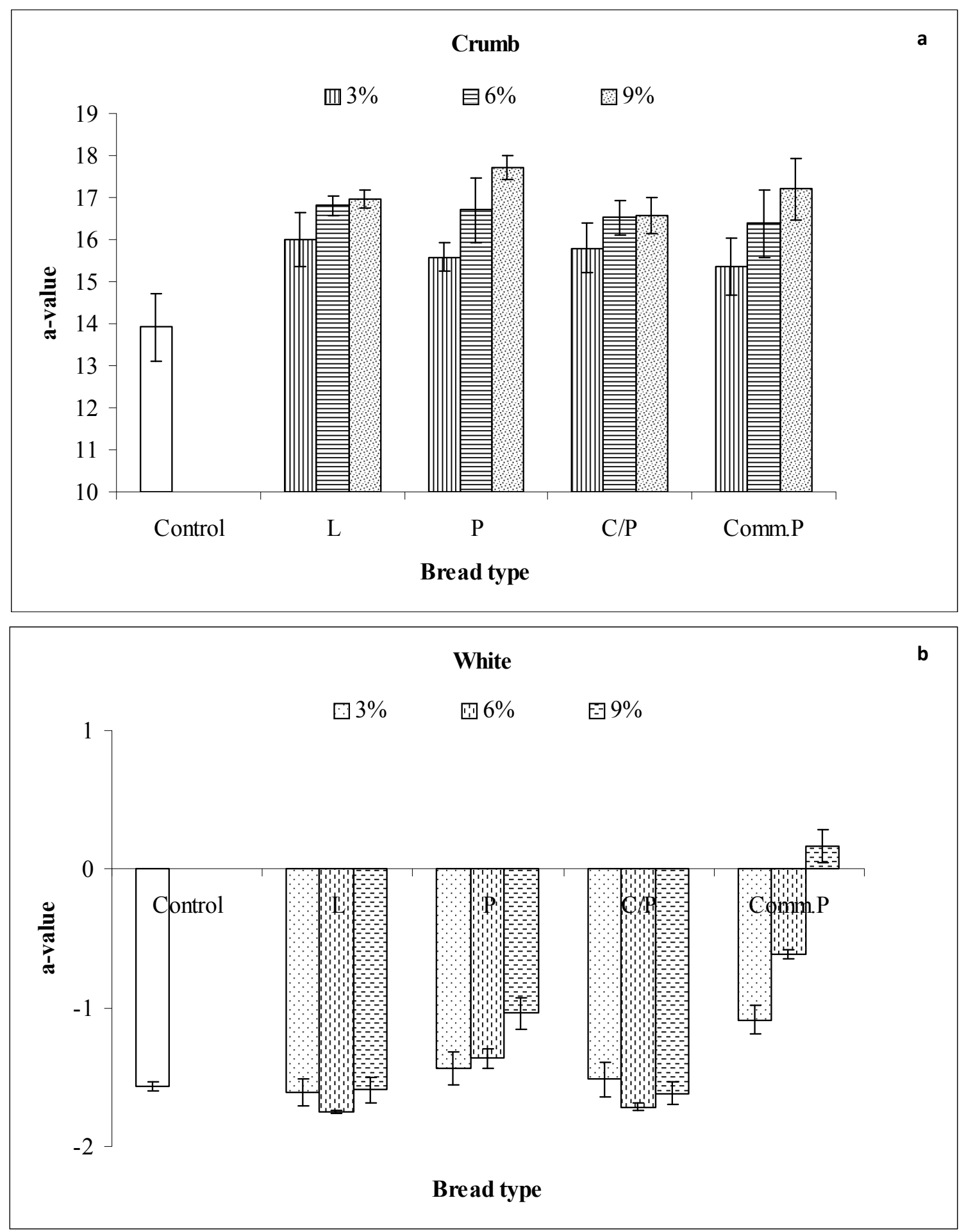

Figure 5. Evaluation of the (a) color parameter of (a) crumb and (b) white of control bread and supplemented bread prepared using $\mathrm{L}$ - Lentil protein concentrate; $\mathrm{P}$ - Pea protein concentrate (in-house); C/P - Chickpea protein concentrate; Comm. P - Commercial pea protein concentrate at 3,6 and $9 \%$ supplementation levels 

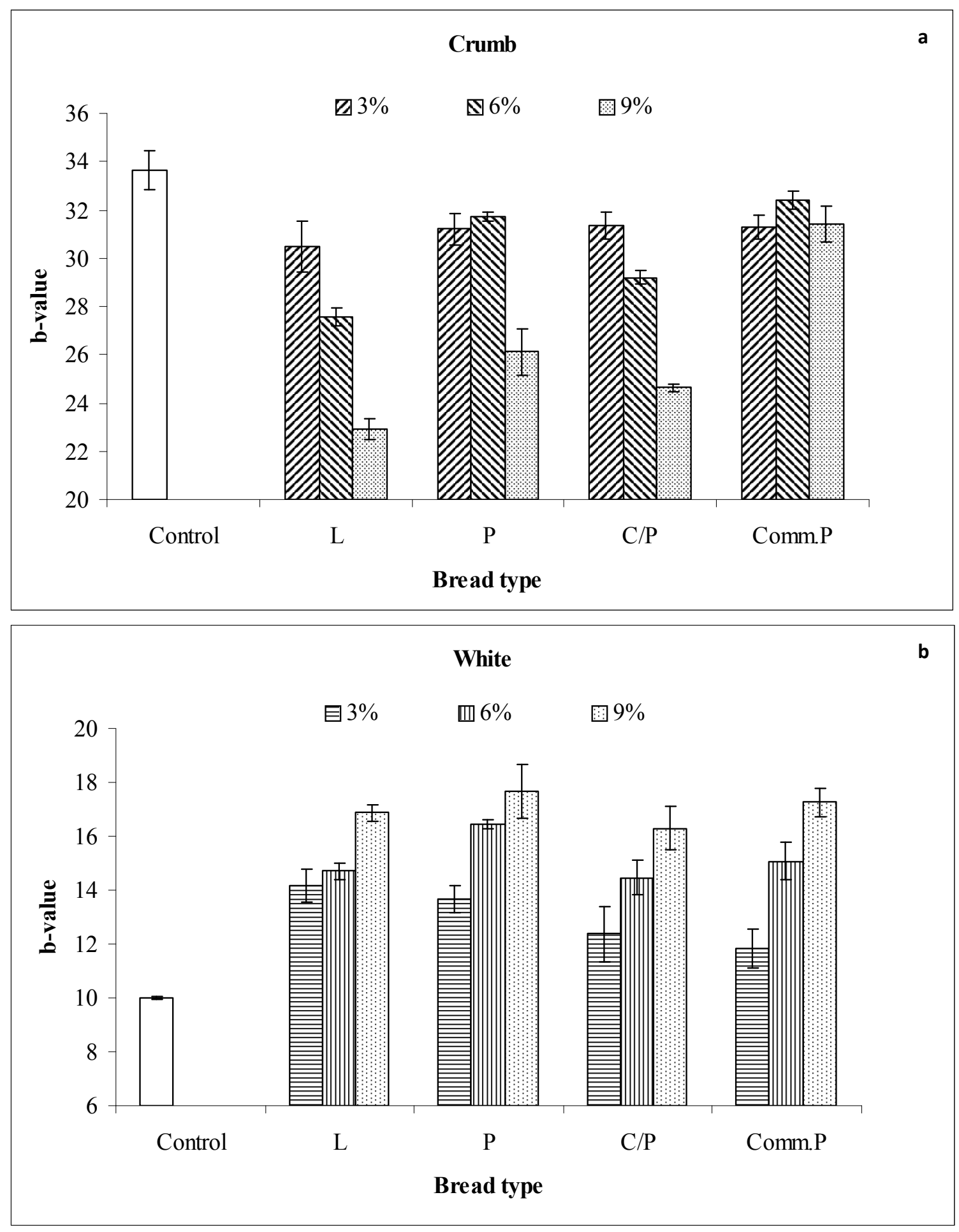

Figure 6. Evaluation of the (b) color parameter of (a) crumb and (b) white of control bread and supplemented bread prepared using $\mathrm{L}$ - Lentil protein concentrate; $\mathrm{P}$ - Pea protein concentrate (in-house); C/P - Chickpea protein concentrate; Comm. P - Commercial pea protein concentrate at 3, 6 and $9 \%$ supplementation levels 

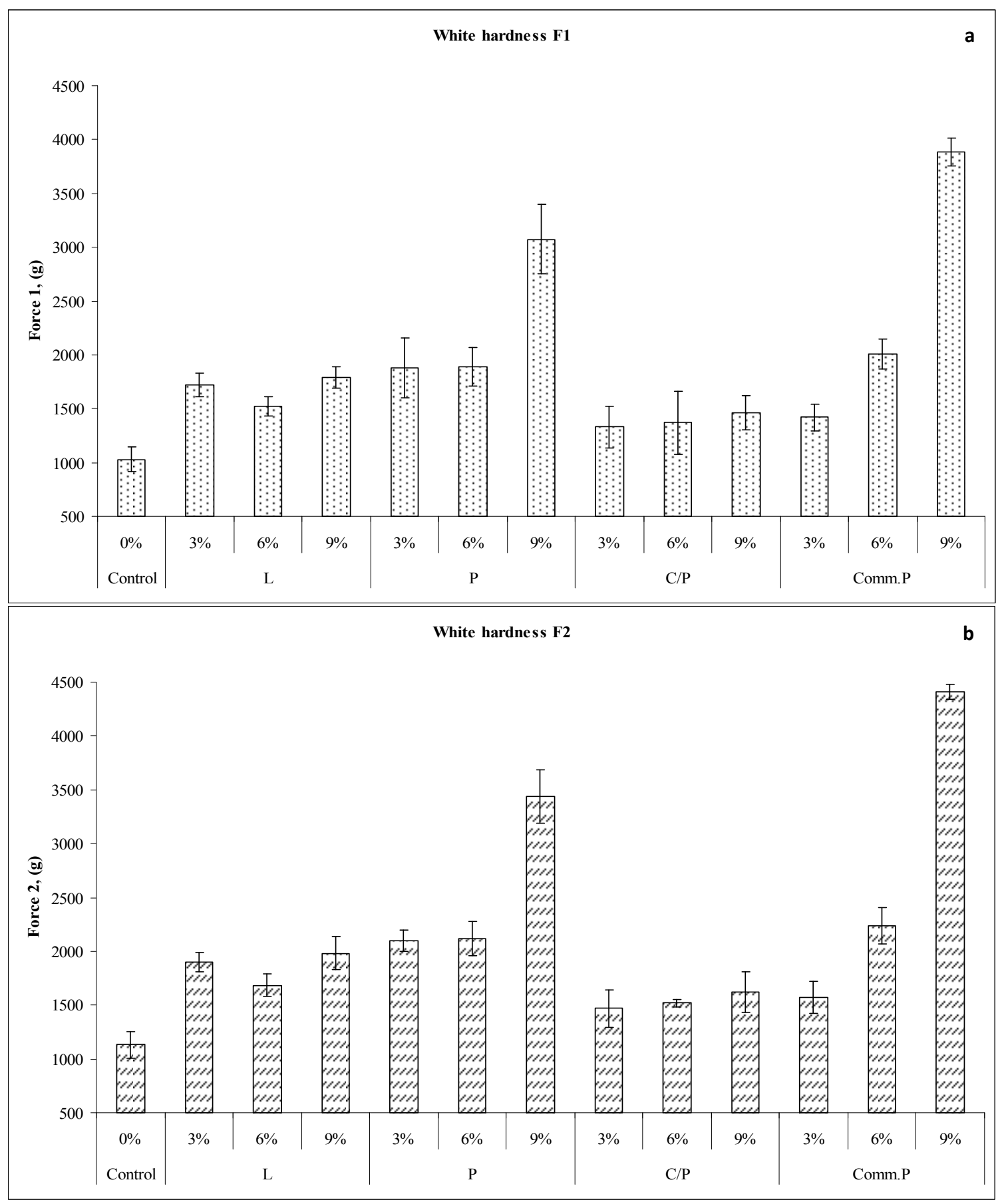

Figure 7: Texture profile analysis (a) hardness 1 and (b) hardness 2 of the white of control bread and supplemented bread prepared using L - Lentil protein concentrate; $\mathrm{P}$ - Pea protein concentrate (in-house); C/P Chickpea protein concentrate; Comm. P - Commercial pea protein concentrate at 3,6 and 9\% supplementation levels

The overall tendency was similar to the results of the hardness1 (Force 1) but the corresponding values were slightly higher which suggests that after the first compression, the bread whites did not resume their initial volume.

Plant proteins and flours are poorly soluble in water and low solubility is one of the most influencing factors of product hardness. Nilufer et al. (2008) reported that low soluble soy protein addition to bread formula significantly increased bread firmness. Moreover, high soy protein content in the bread formula increased the 
toughness of the bread. Addition of high soluble soy protein and soluble fibre, on the other hand, resulted in significantly softer fresher soy breads (Kim \& Moon, 1999). Milk protein addition reportedly improved bread texture (Shon et al., 2009) and this behaviour was positively correlated to the high solubility of whey protein. The presence of residual polysaccharides in the pulse protein ingredients may also have contributed to product hardness (Davidou et al., 1996; Zobel \& Kulp, 1996).

\section{Conclusion}

Wheat flour can be substituted by pulse proteins during bread making, however addition of pulse ingredients can affect product mass volume, color and texture. In this study, the highest bread mass volume was obtained in the control bread. At the 3\% supplementation level, the supplemented breads showed acceptable loaf mass volume but this decreased as the supplementation level was increased especially when pea protein was used. Bread crumb and whites also became darker as the supplementation level was increased and in the lentil supplemented bread, a greener color appeared at the 6 and $9 \%$ supplementation levels. Of the pulse proteins, pea protein had the most significant effect on bread hardness. Furthermore, observed differences in the behaviour of the in-house and commercially produced pea proteins used in this study suggest that the method used to prepare the protein extracts could affect the characteristics of the dough and the baked products. This opens up an interesting avenue of research as more pulse ingredients are processed commercially for the ingredient market. Additionally, the concentration of protein in the pulse product may be of consequence. Overall, the results showed the chickpea protein concentrate which had the lowest protein content to have the greatest potential for use as a supplement in bread making.

\section{Acknowledgment}

Authors would like to thank Mrs. Carole McKinnon from the CRDA/FRDC of Saint-Hyacinthe for the technical support with bread making and baking procedure.

\section{References}

American Association of Cereal Chemists. (2001). Approved methods of the AACC. Method 10-10B, approved January 1983, revised September 1985; Method 10-05, first approved October 2001. The Association. St Paul, MN.

Annapure, U. S., Singhal, R. S., \& Kulkarni, P. R. (1998). Studies on deep-fat fried snacks from some cereals and legume. Journal of Science of Food and Agriculture, 76, 377-382.

Boye, J. I., Aksay, S., Roufik, S., Ribéreau, S., Mondor, M., Farnworth, E. R., \& Rajamohamed, S. H. (2009). Comparison of the functional properties of pea, chickpea and lentil protein concentrates processed using ultrafiltration and isoelectric precipitation techniques. Food Research International, 43(2), 537-546. http://dx.doi.org/10.1016/j.foodres.2009.07.021

Brewer, M. S., Potter, S. M., Sprouls, G., \& Reinhard, M. (1992). Effect of soy protein isolate and soy-fiber on color, physical and sensory characteristics of baked products. Journal of Food Quality, 15(4), 245-262.

Chavan, J. K., Kadam, S. S., \& Salunkhe, D. K. (1986). Biochemistry and technology of chickpea (Cicer arietinum L.) seeds. Critical Reviews in Food Science and Nutrition, 25, 107-158.

Czuchajowska, Z., Paszczynska, B., \& Pomeranz, Y. (1992). Functional properties of psyllium in wheat-based products. Cereal Chemistry, 69, 516-520.

Davidou, S., Le Meste, M., Debever, E., \& Bekaert, D. (1996). A contribution to the study of staling of white bread: Effect of water and hydrocolloid. Food Hydrocolloids, 10, 375-383. http://dx.doi.org/10.1016/S0268-005X(96)80016-6

Dodok, L., Ali, M. A., Hozová, B., Halasová, G., \& Polacek, I. (1993). Importance and utilization of chickpea in cereal technology. Acta alimentaria, 22, 119-129. Retrieved from http://www.refdoc.fr/Detailnotice?idarticle=17465986

Eggum, B. O., \& Beame, R. M. (1983). The nutritive value of seed proteins. In: W. Gottschalk, \& P. H. Muller (Eds), Seed Protein Biochemistry, Genetics and Nutritive Value (pp. 499-531).

Frost, G., Leeds, A. A., Dore, C. J., Madieros, S., Brading, S., \& Dornhorst, A. (1999). Glacaemic index as a determinant of seum HDL-cholesterol concentration. Lancet, 353, 1045-1048.

Gomez, M., Ronda, F., Blanco, C., Caballero, P., \& Apesteguía, A. (2003). Effect of dietary fibre on dough rheology and bread quality. European Food Research and Technology, 216(1), 51-56. 
Goni, I., \& Valentin-Gamazo, C. (2003). Chickpea flour ingredients slows glycemic response to pasta in healthy volunteers. Food Chemistry, 81, 511-515. http://dx.doi.org/10.1016/S0308-8146(02)00480-6

Hoover, W. (1979). Use of soy proteins in baked foods. Journal of the American Oil Chemists' Society, 56(3), 301-303.

Indrani, D., Prabhasankar, P., Rajiv, J., \& Rao, G. V. (2007). Influence of whey protein concentrate on the rheological characteristics of dough, microstructure and quality of unleavened flat bread (parotta). Food Research International, 40(10), 1254-1260. http://dx.doi.org/10.1016/j.foodres.2007.08.005

Kenny, S., Wehrle, K., Stanton, C., \& Arendt, E. K. (2000). Incorporation of dairy ingredients into wheat bread: effects on dough rheology and bread quality. European Food Research and Technology, 210(6), 391-396.

Kim, H., \& Moon, T. W. (1999). Quality attributes of bread with soymilk residue dietary fiber. Food Science and Biotechnology, 8, 245-250.

Laurikainen, T., Härkönen, H., Autio, K., \& Poutanen, K. (1998). Effects of enzymes in fibre-enriched baking. Journal of the Science of Food and Agriculture, 76(2), 239-249.

Livingstone, A. S., Feng, J. J., \& Malleshi, N. G. (1993). Development of nutritional quality evaluation of weaning foods based on malted, popped and dried wheat and chickpea. International Journal of Food Science and Technology, 28, 35-43.

Nilufer, D., Boyacioglu, D., \& Vodovotz, Y. (2008). Functionality of soymilk powder and its components in fresh soy bread. Journal of Food Science, 73(4), C275-C281.

Shon, J., Yun, Y., Shin, M., Chin, K. B., \& Eun, J. B. (2009). Effects of milk proteins and gums on quality of bread made from frozen dough. Journal of the Science of Food and Agriculture, 89(8), 1407-1415.

Vittadini, E., \& Vodovotz, Y. (2003). Changes in the Physicochemical Properties of Wheat- and Soy-containing Breads During Storage as Studied by Thermal Analyses. Journal of Food Science, 68(6), 2022-2027.

Wang, J., Rosell, C. M., \& Benedito de Barber, C. (2002). Effect of the addition of different fibres on wheat dough performance and bread quality. Food Chemistry, 79(2), 221-226. http://dx.doi.org/10.1016/S0308-8146(02)00135-8

Yamsaengsung, R., Schoenlechner, R., \& Berghofer, M. (2010). The effects of chickpea on the functional properties of white and whole wheat bread. International Journal of Food Science and Technology, 45(3), $610-620$.

Zobel, H. F., \& Kulp, K. (1996). The staling mechanism. In: R. E. Hebeda \& H. F. Zobel (Eds), Baked goods freshness (pp. 1-64). New York: Marcel Dekker, Inc. 